\title{
Agriculture in the Maryut District, West of Alexandria.'
}

\section{$T^{H}$} $\mathrm{HE}$ coast district lying to the west of Alexandria and known as Mareotis was well known in Græca-Roman times and for long after for its gardens and vineyards, and even down to the time of the Arab historian Makrisi figs and grapes from there were sold in Alexandria. For several centuries, however, it has been a barren waste except for small patches of barley raised by the nomad Arabs in the more-favoured spots when the winter rains are plentiful. In the report under notice an account is given of an examination made by the Geological Survey and the Ministry of Agriculture of Egypt to determine whether the area offered any prospect of a remunerative return from dry farming or from irrigation by the extension of the westernmost canal of the delta system, the Nubariya.

The district which the report covers is a belt about I $5 \mathrm{~km}$. wide on the shore of the Mediterranean, and it extends from Alexandria to a point about Ioo $\mathrm{km}$. to the westward. Starting from the sea-shore, there is, first, a series of white dunes formed of small rounded oolitic grains which, by the action of the winter rains, unite to form masses of more compact rock. Behind these dunes, which do not exceed ro metres in height, is a narrow depression which is of considerable fertility. Farther inland is a higher limestone ridge, where numerous ruins indicate that it was once well populated. The main depression lies behind this ridge, and is about $4 \mathrm{~km}$. wide; figs and barley are cultivated on the slopes on either side of the saline marsh which occupies the central portion of the depression.

The rainfall, which is limited to the months October-March, varies considerably from year to year, ranging from $100-300 \mathrm{~mm}$., and if rain is scanty in November the barley, which is sown as soon as the October rains occur, may yield a very poor crop.

1 "The Soils and Water Supply of the Maryut District. West of Alexandria." By Dr. W. F. Hume and F. Hughes. (Cairo: Government Press, rgar.)
Full details are given of the physical character of the soil in many parts of the district and at various depths, but what controls all extension of vegetation is the presence of intensely saline water at or near sea-level. On account of this the cultivation of any considerable area is difficult, and the Arabs are able to utilise only the more favoured spots to raise their crops. While it seems probable that about 12,000 acres might be brought under cultivation by the extension of the Nubariya Canal, parts of this area would be too stony for satisfactory cultivation. Generally speaking, a more detailed study of this part, together with more extended contoured surveys, will be necessary before any decision can be reached as to the desirability of irrigation on this part of the desert margin.

A trial of dry farming was made in the Maryut district in the seasons of I917-I8 and I9I8-19, but lack of rain in November seriously damaged the crops. The conclusion was reached that such methods are not likely to be successful owing to the variable character of the rainfall and the patchy nature of good soil.

By sinking wells and utilising the winter rainfall fruit-gardens could probably be developed, and this was the principal form of cultivation in ancient times. Over a large area numerous artificial mounds enclose rectangular areas $(\mathrm{karm})$, which were certainly at one time gardens. These were watered from wells and from the run-off after winter rains had fallen on the enclosed land and some of the water had been conserved in the central area.

Though the investigation has not led to a prospect of a large extension of Egypt's cultivable area, it has placed our knowledge of the Maryut district on a firm basis, and has shown what developments there are possible. The report is well illustrated by maps and photographs which show the character of this coast region.

\section{Fisheries Biology: ${ }^{1}$}

SOME notable papers on marine biology of interest in fishery investigations are contained in the last number of the Journal of the Marine Biological Association. Mr. E. Ford takes up a matter that has hitherto received very little attention-the life-history of the dogfishes. Now that these animals are being utilised as human food (particularly the spur-dog, which: enters the markets as "flake") their biology has utilitarian value, and this paper is, therefore, of much interest. The author deals mainly with phases in the reproductive cycles of the common species (the spur-dog, the rough-dog, the nurse-hound, and the sweet-william). The spur-dog and nurse-hound are viviparous, and the prolonged period of incubation in utero deduced by Mr. Ford will come as a surprise to most readers; this, in the case of the spur-dog; may extend to twenty-five months. Biologically, the reproductive processes in the dogfishes are of immense interest, and one may hope that Mr. Ford may continue his investigations and give us much needed information as to the natural history and physiology of these animals.

Dr. Marie Lebour continues her well-known work on the food of baby fish. Quite lately this subject has become one of extraordinary importance in fishery investigation, particularly in view of the implications

1 Journal of the Marine Biological Association, vol. I2, No. 3 , Plymouth, September, 1921. NO. 2722 , VOL. IO8] of Dr. Johan Hjort's work on the cod and herring. That there are natural "crises" in the conditions that rule the abundance of sea-fishes is now established, and upon these crises-far more, perhaps, than upon any reasonable variations in the intensity of fishing-depend the quantities of marketable fish present in the sea in any year. There is a short period in the life of the ordinary fish when, its supply of food-yolk being exhausted, suitable pelagic organisms must be found and eaten. The periods of multiplication of the latter are variable, to some extent, from year to year, and so are the spawning periods of the fishes. In some years, therefore, abundant food may be forthcoming just at the timre of disappearance of the larval fishes' yolk-sac, but in other years this food may fail, its production occurring well before or after the time when the larval fish transformation occurs in greatest degree. A heavy mortality in the baby fishes must be followed, two or three years later, by a scarcity of the adults, and vice versa.

For a proper treatment of this problem we require tc know ( $\mathrm{r}$ ) the kinds of food eaten bv larval and: post. larval fishes, (2) the periods of maximum production of the food, and (3) the maximum spawning periods of the fishes. The first auestion is being investigated by Dr. Lebour with much success, and in this paper she deals with the food of baby herrings, sprats, and 